\title{
CARA PANDANG EMPOWERMENT DALAM PROGRAM PADAT KARYA DI DINAS TENAGA KERJA DAN TRANSMIGRASI KABUPATEN KULON PROGO
}

\author{
Iman Amanda Permatasari \\ Sekolah Tinggi Pembangunan Masyarakat Desa “APMD” Yogyakarta \\ Email: imanamanda14@gmail.com
}

\begin{abstract}
ABSTRAK
Membahas empowerment di Kabupaten Kulon Progo belum ada yang merujuk pada Dinas Tenaga Kerja dan Transmigrasi (Disnakertrans) Kulon Progo, khususnya pada satu program yang dilaksanakan. tujuan penelitian ini untuk mengetahui cara pandang empowerment dalam program padat karya di dinas tenaga kerja dan transmigrasi kabupaten Kulon Progo. Metode penelitian yang digunakan adalah kualitatif. Sementara hasil temuan dalam penelitian ini bahwa program Padat Karya yang diklaim sebagai bagian empowerment oleh Disnakertrans Kabupaten Kulon Progo, pada hakikatnya tidak memenuhi konsep empowerment. Hal tersebut dilihat dari beberapa hal, yaitu: 1) ditinjau dari makna empowerment, Padat Karya tidak bisa secara spesifik menyasar penduduk-penduduk lemah tertentu. Sasarannya adalah petani yang sedang tidak bertani. Hal ini menurut penulis bukan bentuk kelemahan; 2) program ini hanya memiliki dua dari ketiga prinsip empowerment, yakni prinsip mengerjakan dan akibat; 3) orientasi perkembangan dari Padat Karya merujuk pada peningkatan ekonomi saja, bukan pada keberlanjutan program tersebut melalui berdayanya masyarakat petani; 4) konsep keberlangsungan pada empowerment tidak bisa penulis lihat, program hanya akan berjalan apabila kesempatan untuk melakukan usulan dilakukan, sehingga masyarakat tidak mandiri, kreatif, ataupun inovatif.
\end{abstract}

Kata Kunci: Perencanaan; Pembangunan; Empowerment; Padat Karya

\begin{abstract}
Empowerment Discussed in Kulon Progo Regency there is no reference to the Kulon Progo Manpower and Transmigration Office (Disnakertrans), especially in one program that was implemented. The purpose of this study was to determine the perspective of empowerment in a Padat Karya program at the Manpower and Transmigration Office of Kulon Progo Regency. The research method used is qualitative. Meanwhile, the findings in this study are that the Padat Karya program which is claimed as part of empowerment by the Manpower and Transmigration Office of Kulon Progo Regency, in essence does not fulfill the concept of empowerment. This can be seen from several things, namely: 1) in terms of empowerment of meaning, Padat Karya cannot specifically target certain residents. The target is farmers who are not farming. According to the author, this is not a form of weakness; 2) this program only has two of the three principles of empowerment, namely doing tasks and results; 3) the development orientation of the Intensive Work Referring to economic improvement only, not to the development community through the empowerment of farmers; 4) the concept of sustainability in empowerment cannot be seen, the program will only run if
\end{abstract}


the community has the opportunity to do it, so it is not independent, creative, or innovative.

Keywords: Planning; Development; Empowerment; Padat Karya.

\section{Informasi Artikel}

Diterima: Oktober 2021, Disetujui: November 2021, Dipublikasikan: Desember 2021

DOI: https://doi.org/10.47431/governabilitas.v2i2.114

\section{PENDAHULUAN}

Pemberdayaan atau empowerment adalah bagian dari konsep pembangunan masyarakat dalam bidang ekonomi dan politik. Cirinya terdiri dari people centered (berpusat kepada rakyat), participatory (partisipasi), empowering (memberdayakan masyarakat), dan sustainable (berkelanjutan) (Musa, 2017). Oleh karena itu, pemberdayaan merupakan usaha untuk memberikan dorongan, motivasi dan hal lainnya yang dapat menguatkan potensi masyarakat, sehingga mereka bisa lebih kreatif dan inovatif, serta kesejahteraannya terjamin. Pemberdayaan selalu berhubungan dengan pribadi individu atau kelompok, hanya saja terkadang mereka tidak mengetahui apa potensinya. Keberadaan pilar-pilar eksternal untuk memberikan dukungan jelas dibutuhkan. Misalnya pada satu kelompok masyarakat daerah, dibutuhkan peran pemerintah untuk menggali potensi. Selain itu juga dibutuhkan kelompok-kelompok lain yang lebih kuat untuk bisa memfasilitasi. Keseluruhan elemen tersebut harus menjadi satu dan berjalan beriringan, sehingga konsep dan prinsip pemberdayaan dapat dilakukan secara optimal.

Di Kabupaten Kulon Progo misalnya, program-program pemberdayaan telah banyak dilakukan oleh dinas-dinas terkait, termasuk Dinas Tenaga Kerja dan Transmigrasi (Disnakertrans) Kabupaten Kulon Progo. Dinas ini memiliki fungsi penyelenggaraan urusan Pemerintahan daerah dan Tugas Pembantuan dalam bidang tenaga kerja dan transmigrasi. Tugasnya terdiri dari: 1) pengelolaan bidang hubungan industrial dan perlindungan tenaga kerja; 2) pengelolaan bidang pengembangan dan penempatan tenaga kerja; 3) pengelolaan bidang transmigrasi; dan 4) pengelolaan ketatausahaan (nakertrans.kulonprogokab.go.id, 2019). Salah satu program yang disebutkan oleh Disnakertas Kabupaten Kulon Progo sebagai bentuk empowerment adalah program Padat karya. Program ini mencoba memberdayakan masyarakat dalam 
bidang fisik, seperti pembuatan jalan desa, saluran air, dan irigasi. Melalui padat karya, pemerintah memberikan tambahan pekerjaan di waktu luang bagi masyarakat petani ketika tidak sedang bertani, agar mendapatkan pemasukan lain. Namun, apakah kegiatan ini benar-benar efektif dilaksanakan?

Penelitian tentang pemberdayaan di Kabupaten Kulon Progo banyak dilakukan. Misalnya (Rahayu et al., 2016) mengkaji tentang Pengembangan Community Based Tourism Sebagai Strategi Pemberdayaan Ekonomi Masyarakat di Kabupaten Kulon Progo Daerah Istimewa Yogyakarta, dalam Jurnal Penelitian Humaniora, Vol. 21, No. 1. Hasil penelitian tersebut menyebutkan bahwa pengembangan CBT sebagai pemberdayaan ekonomi masyarakat dilakukan melalui pengembangan destinasi wisata, pemasaran pariwisata dan pengembangan kemitraan. Penghambat program ini adalah infrastruktur yang tidak mendukung, partisipasi masyarakat masih rendah, dan ketidakmaksimalan kemitraan yang terjalin. Penulis dapat melihat bahwa Rahayu, dkk mengkaji pemberdayaan dari sisi pengembangan CBT dan pariwisata.

Penelitian selanjutnya adalah (Erwinsyah et al., 2020) yang membahas tentang Efektivitas Belabeliku.Com Dalam Pemberdayaan Masyarakat Berbasis E-Commerce Kabupaten Kulon Progo Tahun 2018, pada Jurnal Moderat, Volume 6, Nomor 3. Hasil dari penelitian ini memperlihatkan bahwa teknologi yang diadopsi dalam pemberdayaan ekonomi masyarakat adalah belabeliku.com yang diperuntukan bagi pelaku UMKM dan masyarakat Kulon Progo. Program tersebut dikatakan mampu membantu masyarakat dalam meningkatkan kesejahteraan. Dari penelitian tersebut penulis dapat melihat perspektif empowerment yang dikaji melalui pemanfaatan teknologi.

Selanjutnya Isyaroh dan Atmojo menulis tentang Efektivitas Toko Milik Rakyat (TOMIRA) dalam Mewujudkan Pemberdayaan Masyarakat di Kabupaten Kulon Progo Tahun 2018, dalam Jurnal Ilmu Sosial dan Politik, Volume 05 Nomor 01. Hasil penelitian ini menyebutkan bahwa Bupati Kulon Progo menggencarkan Gerakan BelaBeli Kulon Progo melalui dibangunnya program Tomira (Toko Milik Rakyat) oleh Dinas Koperasi dan UMKM. Program dilaksanakan dengan melaksanakan pelatihan terhadap koperasi dan UMKM. Penelitian ini juga menjelaskan bahwa produk UMKM yang harus masuk dalam Tomira minimal 20\% dari seluruh barang (Isyaroh \& Atmojo, 2020). Melalui program tersebut, penulis melihat adanya komitmen pemerintah untuk membangun potensi lokal daerah Kulon Progo. Pembangunan Tomira memberikan 
wadah yang sangat nyata dalam membantu masyarakat menjual hasil produksi lokal untuk digunakan oleh masyarakat sendiri.

Penelitian-penelitian terdahulu yang membahas empowerment di Kabupaten Kulon Progo belum ada yang merujuk pada Dinas Tenaga Kerja dan Transmigrasi (Disnakertrans) Kulon Progo, khususnya pada satu program yang dilaksanakan. Oleh karena itu, akan sangat menarik untuk melakukan penelitian mengenai hal tersebut guna melihat bagaimana cara pandang yang digunakan. Penulis akan mengambil program Padat Karya untuk meninjau hal tersebut.

\section{TINJAUAN TEORETIS: MAKNA EMPOWERMENT}

Pemberdayaan masyarakat merupakan usaha yang dilakukan oleh masyarakat dalam memperbaiki kehidupannya dengan basis daya mereka sendiri dengan mengoptimalkan daya dan meningkatkan posisi tawar yang dimiliki, baik dibantu ataupun tanpa bantuan dari pihak luar. Oleh karena itu, pemberdayaan menempatkan kekuatan masyarakat sebagai pilar utama menghindari pihak luar yang ingin mematikan kemandirian masyarakat (Mustanir, 2019). Dalam penelitiannya yang lain, Mustanir juga melakukan review pada beberapa penelitian yang hasilnya memberikan penekanan bahwa pemberdayaan ditujukan pada kemampuan seseorang yang tidak memiliki kekuatan. Harapannya, mereka menjadi berdaya dalam memenuhi kebutuhan dasar, mampu memperlihatkan sumber-sumber produktif yang bisa meningkatkan kesejahteraan, dan keinginan untuk berpartisipasi pada setiap proses pembangunan beserta keputusan yang tentu akan mempengaruhi kehidupan mereka (Mustanir et al., 2019).

Melihat definisi di atas, penulis dapat menarik kesimpulan bahwasannya pemberdayaan mengupayakan setiap potensi, termasuk kelemahan individu atau kelompok agar kemudian memiliki power dan berdaya sendiri. Power yang dimiliki harus terus-menerus berlanjut, sekalipun tidak ada yang menopang. Dalam artian, individu atau kelompok harus mampu mandiri dan berdiri sendiri.

\section{PRINSIP, FAKTOR, DAN KECENDERUNGAN EMPOWERMENT}

Menurut Mardiankanto seperti yang dikutip oleh (Murtiningrum \& Oktoyoki, 2019), pemberdayaan memiliki beberapa prinsip sebagai berikut: a) Mengerjakan. Pemberdayaan harus melibatkan masyarakat secara maksimal untuk dapat 
mengimplementasikan sesuai. Harapannya, masyarakat akan belajar dari proses tersebut; b) Akibat. Pemberdayaan harus memunculkan pengaruh baik dan memberikan manfaat karena dapat berkorelasi dengan semangat dalam mengikuti pemberdayaan; dan c) Asosiasi. Pemberdayaan harus memiliki keterkaitan dengan kegiatan lain.

Meskipun demikian, pemberdayaan memiliki sisi lain. Hal ini diungkapkan oleh (Anomsari \& Abubakar, 2019). Menurutnya, terdapat dua faktor paling penting dalam perwujudkan pemberdayaan melalui partisipasi yang dapat menghambat pemberdayaan, yaitu: a) Pemberdayaan merupakan hal kompleks, multidimensional dan berkelanjutan. Oleh karena itu, tidak mudah untuk dapat memprediksi keberlangsungan pemberdayaan; dan b) Keterbatasan partisipasi masyarakat dalam penerapan kebijakan, sehingga power yang dimiliki masyarakat belum meningkat. (Ulum \& Anggaini, 2020) mengatakan pemberdayaan dapat mengandung dua kecenderungan, yaitu; a) kecenderungan utama (pemberdayaan menekankan pada proses memberi atau mengalihkan sebaian kekuatan agar lebih mandiri); dan b) kecenderungan sekunder (menekankan pada proses stimulasi dorongan dan motivasi individu agar lebih berdaya). Sementara dalam pelaksanaannya, terdapat beberapa hal yang harus diperhatikan. Sebut saja akses kepada informasi, partisipasi, akuntabilitas, dan kapasitas organisasi lokal. Kedua kecenderungan di atas menurut penulis berhubungan dengan strategi pemberdayaan masyarakat itu sendiri. Kecenderungan utama dan sekunder berbicara tentang proses bagaimana pemberdayaan dilakukan. Apakah secara memberikan sebagian kekuatan, atau justru dengan memberikan dorongan kepada masyarakat yang dikatakan lemah.

\section{KEGAGALAN PROGRAM PEMBANGUNAN BERBASIS EMPOWERMENT}

Selanjutnya, sehubungan program-program pembangunan yang orientasinya adalah pemberdayaan bisa saja mengalami kegagalan. Faktor utama kegagalan tersebut yakni ketidakberpihakan kepada kelompok penduduk miskin, dan kegiatan sosial untuk ekonomi produktif dalam wadah yang ada. Hal lainnya ditentukan oleh penguatan lembaga sosial ekonomi dan pembinaan yang sebaiknya dilakukan atas asas pembelajaran, karena pemberdayaan adalah solusi dari kegagalan pembangunan sebelumnya. Oleh karena itu, tiga cara yang harus dilakukan adalah enabling, empowering dan protection (Afiyah, 2011). Menurut Edi Suharto seperti yang dikutip oleh (Soeprodjo et al., 2020) enabling adalah usaha dalam membuat iklim yang bisa 
mengembangkan potensi masyarakat secara optimal, karena pemberdayaan ditujukan guna memberi kebebasan bagi masyarakat dari sekat struktural dan kultur yang menghambat. Sementara itu, menurut Kartasasmita seperti yang dikutip oleh Mustangin, empowering memiliki makna sebagai memperkuat potensi atau daya yang dimiliki masyarakat (Mustangin et al., 2017). Selanjutnya (Widiyawati, 2020) mengutip Friedmann yang mengatakan bahwa protecting dilakukan untuk memberikan perlindungan dan pembelaan terhadap kepentingan masyarakat lemah dengan menempatkan partisipasi dalam pengambilan keputusan sebagai unsur penting.

Berkaitan dengan pengambilan keputusan, (Askar, 2019) menyatakan dalam penelitiannya bahwa dimensi perencanaan membutuhkan pengambilan keputusan yang rasional dan bertanggung jawab. Bahkan dalam tahap implementasi, paradigma yang ada harus diintegrasikan dalam konsep matang pemberdayaan masayrakat. Begitu pun dalam pengawasan, mental aparat dan mekanisme pengawalan program harus terus diperbaiki. Dan dalam partisipasi, seluruh masyarakat memiliki hak yang sama.

\section{PERAN PEMERINTAH DALAM EMPOWERMENT}

Peran pemerintah dalam pemberdayaan dilihat dari fungsi yang menyertainya, yaitu regulator, dinamisator, dan fasilitator. Ketiganya dikatakan harus dilakukan beriringan, sejalan tanpa adanya pemisahan (Musa, 2017). Menurut Arief seperti yang dikutip Firdaus, peran sebagai regulator, ialah pemerintah harus mempersiapkan arah dalam melakukan penyeimbangan penyelenggaraan pembangunan dengan cara menerbitkan peraturan, dan tata tertib administrasi pembangunan (Firdaus, 2020). Kemudian, Mardlatillah dan Hidayat juga mengutip pendapat Arief tentang dinamisator yang memiliki makna pemerintah harus mampu menggerakkan partisipasi dari segala pihak ketika proses pembangunan mengalami hambatan. Hal tersebut dilakukan melalui bimbingan dan pengarahan yang intensif dan efektif (Mardlatillah \& Hidayat, 2019).

\section{METODE PENELITIAN}

Penelitian ini adalah penelitian kualitatif deskriptif. Jenis dan sumber data yang digunakan adalah data primer dan sekunder. Data primer didapatkan dari lapangan, melalui wawancara dan dokumentasi. Data sekunder bersumber dari artikel jurnal dan media daring yang sesuai atau relevan dengan penelitian. Unit analisa data pada penelitian ini adalah Program Padat Karya di Dinas Tenaga Kerja dan Transmigrasi 
Kabupaten Kulon Progo. Selanjutnya, teknik analisa data yang digunakan yaitu reduksi data, penyajian data, dan penarikan kesimpulan. Lokasi penelitian adalah Disnakertrans Kabupaten Kulon Progo, dan dilaksanan pada tahun 2020.

\section{PEMBAHASAN}

\section{PADAT KARYA DAN EMPOWERMENT}

Program Padat Karya memiliki tujuan untuk memberikan lapangan pekerjaan bagi masyarakat, sekaligus memperbaiki akses dalam memperlancar roda perekonomian. Pada padat karya Desa Gulurojo pada tahun 2017, pekerjaan yang dilaksanakan adalah rapat beton dengan volume $350 \times 3 \times 0,10 \mathrm{~m}$ dan talud dengan volume $75 \times 1,5 \times 0,30 \mathrm{~m}$. kegiatan tersebut berjalan dalam waktu 12 hari, dengan melibatkan 88 tenaga kerja (nakertrans.kulonprogokab.go.id, 2017). Pada tahun 2020, Pemkab Kulon Progo melalui Disnakertrans melaksanakan Padat Karya Infrastruktur Belanja Hibah kepada Lembaga Pemberdayaan Masyarakat Kalurahan. Sumber dana berasal dari APBD Kulon Progo Perubahan Anggaran Tahun 2020. Sasarannya adalah 51 lokasi di Kulon Progo dengan nilai dana Rp. 4.360.000.000 (Kalibawang.kulonprogokab.go.id, 2020).

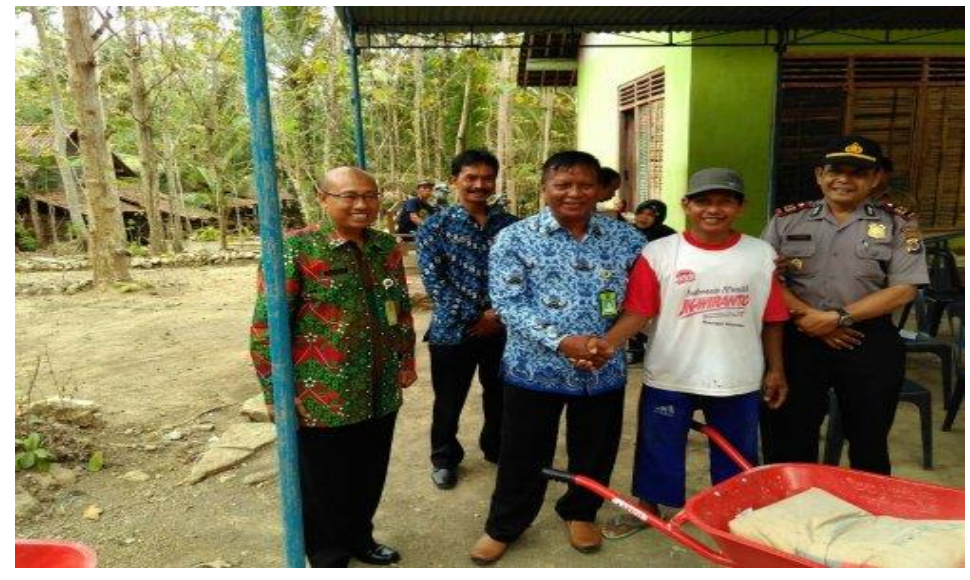

\section{Gambar 1. Contoh Program Padat Karya di Desa Gulurejo Kecamatan Lendah Sumber: nakertras.kulonprogokab.go.id (2017)}

Program Padat Karya merupakan usaha Disnakertrans Kabupaten Kulon Progo untuk memberdayakan masyarakat dalam bidang fisik. Masyarakat yang menjadi sasaran adalah masyarakat petani. Sedikit penjelasan bahwa di Kabupaten Kulon Progo, banyak penduduk berprofesi sebagai petani. Mengingat bahwa pekerjaan tersebut pasti memiliki banyak waktu luang yang dihabiskan ketika tidak bertani, maka muncullah prakarsa untuk membuat program ini. Harapannya, masyarakat tetap bisa mendapatkan pemasukan dan tidak menganggur pada waktu-waktu kosongnya. 
Melihat kondisi tersebut, maka penulis dapat melihat bahwa program ini tidak bisa secara spesifik menyasar penduduk-penduduk lemah tertentu. Sasarannya adalah petani yang sedang tidak bertani. Hal ini menurut penulis bukan bentuk kelemahan. Ditambah lagi apabila mereka tidak memiliki potensi atau kemampuan dalam bidang fisik seperti membuat jalan. Hal ini secara otomatis bertolak belakang dengan makna pemberdayaan yang disampaikan oleh (Mustanir et al., 2019), di mana pemberdayaan ditujukan pada kemampuan seseorang yang tidak memiliki kekuatan sehingga mereka berdaya dalam meraih kesejahteraannya. Dengan kata lain, secara makna empowerment, penulis tidak melihat keselarasan antara empowerment dengan Padat Karya.

\section{PADAT KARYA DITINJAU DARI PRINSIP EMPOWERMENT}

Penulis akan mencoba menganalisis kesesuaian antara prinsip secara teori dan yang terjadi di lapangan. Menurut Mardiankanto seperti yang dikutip oleh (Murtiningrum \& Oktoyoki, 2019), pemberdayaan memiliki prinsip mengerjakan, akibat, dan asosiasi.

a) Mengerjakan. Pemberdayaan melibatkan masyarakat secara maksimal untuk dapat mengimplementasikan program. Program padat karya jelas melibatkan masyarakat secara penuh, karena sasarannya adalah masyarakat. Bahkan usulan setiap orang yang akan mengikuti program tersebut juga bersumber dari masyarakat, terutama desa. Oleh sebab itu, dapat dikatakan bahwa program Padat Karya memenuhi standar prinsip mengerjakan.

b) Akibat. Pemberdayaan harus memunculkan pengaruh baik dan memberikan manfaat. Pengaruh yang didapatkan dari program ini adalah masyarakat memiliki pendapatan lain selain dari hasil bertani, sehingga mereka memiliki semangat dalam mengikuti kelanjutan programnya. Meskipun, setiap kali diadakan program ini tidak mengambil terlalu banyak sasaran. Penulis dapat melihat ini sebagai bentuk keinginan untuk memberdayakan dirinya sendiri, melalui peningkatan skill melakukan pembangunan dan peningkatan pendapatan.

c) Assosiasi. Pemberdayaan memiliki keterkaitan dengan kegiatan lain. Pada poin ini, penulis tidak menemukan kesamaan antara teori dengan praktik di lapangan. Hal tersebut dikarenakan program Padat Karya merupakan bentuk program sendiri tanpa ada ikatan dengan program lain yang serupa. Sebut saja 
pembangunan jalan yang biasanya dilakukan langsung oleh pemerintah desa melalui Alokasi Dana Desa (ADD). Temuan yang penulis lihat justru adanya tumpang tindih proses Padat Karya dinas dengan Padat Karya Desa. Meskipun dari hasil wawancara disebutkan bahwa dalam pelaksanaannya, Disnakertrans telah memastikan bahwa jalan yang dibangun tidak sama dengan jalan yang dibangun menggunakan ADD.

Melihat hasil temuan di lapangan, penulis dapat memberikan kesimpulan bahwa program ini hanya memiliki dua dari ketiga prinsip di atas. Kita tidak bisa menyebutnya sebagai bagian dari empowerment. Secara jelas ini bertolak belakang dengan teori Mardikanto di atas.

\section{PADAT KARYA DITINJAU DARI KECENDERUNGAN EMPOWERMENT}

Disnakertrans memberikan stimulasi dorongan kepada masyarakat petani agar lebih berdaya. Hal ini dilakukan dengan melibatkan masyarakat pada proses penentuan program, salah satunya Padat Karya. Padat karya bersumber dari masyarakat desa yang kemudian disuarakan melalui Musrenbang Desa, naik ke Musrenbang Kecamatan dan seterusnya sampai akhirnya bisa sampai di daerah. Daerah menyampaikan proposal kegiatan tersebut ke Bappeda untuk ditinjau oleh Bupati terkait kelayakan program tersebut. Hal ini menandakan bahwa kecenderungan empowerment yang muncul dari program padat karya seolah merujuk pada kecenderungan sekunder seperti yang dikatakan oleh (Ulum \& Anggaini, 2020) bahwa kecenderungan sekunder menekankan pada proses stimulasi dorongan dan motivasi individu agar lebih berdaya.

Apabila ditinjau lebih jauh, kecenderungan ini tidak sepenuhnya seperti empowerment dikarenakan dorongan yang diberikan hanya berupa fasilitasi dana saja. Seperti hasil wawancara yang peneliti peroleh, nama-nama masyarakat yang terpilih untuk mengikuti Padat Karya adalah usulan dari desa, sementara Disnakertran hanya melakukan koordinasi saja dengan Lembaga Pemberdayaan Masyarakat Kelurahan (LPMK) yang menjadi motor penggeraknya. Hal ini jelas bertolak belakang dengan teori (Musa, 2017) yang menyatakan bahwa fungsi pemerintah dalam pemberdayaan adalah sebagai regulator, dinamisator, dan fasilitator, yang harus dilakukan secara beriringan tanpa adanya pemisahan. 


\section{PADAT KARYA DITINJAU DARI PROSES EMPOWERMENT}

Padat karya sebagai program rutin yang dilaksanakan setiap tahun oleh Disnakertrans Kabupaten Kulon Progo adalah sebuah upaya yang dilakukan untuk mendukung masyarakat petani dalam mendapatkan pemasukan tambahan. Program ini berasal dari usulan masyarakat melalui desa terkait. Hakikatnya sebetulnya sudah mengarah pada partisipasi. Hanya saja, seharusnya Disnakertrans yang lebih dahulu mencari tahu apa yang menjadi potensi masyarakat. Apakah sebetulnya program tersebut layak dilanjutkan, ataukah justru terdapat program lain yang bisa lebih memberdayakan masyarakat dalam hal ketenaga kerjaan. Selanjutnya, orientasi perkembangan dari Padat Karya merujuk pada peningkatan ekonomi saja, bukan pada keberlanjutan program tersebut melalui berdayanya masyarakat petani. Konsep pemberdayaan adalah meningkatkan perekonomian melalui peningkatan potensi, salah satunya potensi lokal, sehingga memiliki power. Program Padat Karya hanya akan dilaksanakan ketika program diajukan kembali. Dengan kata lain, sekalipun dilakukan hampir setiap tahun, tetapi setiap tahunnya kegiatan teraksana tidak lebih dari tiga minggu.

Oleh karena itu, konsep keberlangsungan pada empowerment tidak bisa penulis lihat. Kita tidak bisa menganggap Padat Karya sebagai bagian dari empowerment hanya karena berasal dari prakarsa masyarakat. Seperti pendapat (Askar, 2019) yang menyatakan bahwa dalam implementasi paradigma yang ada harus diintegrasikan dalam konsep matang pemberdayaan masyarakat. Penulis meyakini bahwa integrasi di sini tekait program pemerintah dengan partisipasi, potensi, dan keberlangsungan program pemberdayaan.

\section{OUTCOME PROGRAM PADAT KARYA}

Menurut hasil wawancara, Disnakertrans Kabupaten Kulon Progo tidak bisa melihat secara jauh outcome apa yang muncul dari program tersebut karena pengelolaan program lebih nyata dilakukan oleh Desa dan LPMK. Disnakertrans hanya berperan sebagai fasilitator yang tidak mendalam ikut dalam pelaksanaan program. Selanjutnya pihak Disnakertrans mengatakan bahwa ketika bertanya kepada masyarakat hal yang didapat adalah respons positif mengenai kepuasan menggunakan jalan baru hasil dari Padat Karya. Hal ini mengantarkan penulis pada kesimpulan bahwa yang dirasakan oleh masyarakat ada pada titik tersebut. 
Melihat kenyataan bahwa program hanya dilaksanakan paling lama tiga minggu dalam satu tahun, tidak menunjukkan konsep berkelanjutan. Masyarakat hanya akan mengikuti program apabila kesempatan untuk melakukan usulan dilakukan. Berarti masyarakat menjadi bergantung pada Disnakertrans dalam proses perencanaan pembangunan melalui program padat karya. Padahal konsep dari empowerment merujuk pada kata kemandirian. Artinya ketika pemerintah dan pihak lain lepas tangan, masyarakat harus mampu melanjutkan program tersebut. Masyarakat harus menjadi inovatif dan kreatif. Sejauh pengamatan penulis, masyarakat belum sampai pada tahap tersebut. Hal ini belum bisa memenuhi ciri dari empowerment yang disampaikan (Musa, 2017), bahwasannya empowerment memiliki ciri people centered (berpusat kepada rakyat), participatory (partisipasi), empowering (memberdayakan masyarakat), dan sustainable (berkelanjutan).

\section{KESIMPULAN}

Pada akhir tulisan ini, peneliti memberikan kesimpulan bahwa program Padat Karya yang diklaim sebagai bagian empowerment oleh Disnakertrans Kabupaten Kulon Progo, pada hakikatnya tidak memenuhi konsep empowerment. Hal tersebut dilihat dari beberapa hal, yaitu: 1) ditinjau dari makna empowerment, Padat Karya tidak bisa secara spesifik menyasar penduduk-penduduk lemah tertentu. Sasarannya adalah petani yang sedang tidak bertani. Hal ini menurut penulis bukan bentuk kelemahan; 2) program ini hanya memiliki dua dari ketiga prinsip empowerment, yakni prinsip mengerjakan dan akibat; 3) orientasi perkembangan dari Padat Karya merujuk pada peningkatan ekonomi saja, bukan pada keberlanjutan program tersebut melalui berdayanya masyarakat petani; 4) konsep keberlangsungan pada empowerment tidak bisa penulis lihat, program hanya akan berjalan apabila kesempatan untuk melakukan usulan dilakukan, sehingga masyarakat tidak mandiri, kreatif, ataupun inovatif.

Pelajaran yang bisa diambil dari kasus ini adalah bahwa konsep empowerment yang sesungguhnya tidak hanya sampai pada keberhasilan menyaring partisipasi masyarakat ke dalam sebuah program, tetapi juga terkait integritas pemerintah dan masyarakat dalam melakukan perencanaan pembangunan. Kedua pihak dan pihak lain di luar itu harus berjalan seiringan untuk bisa mencapai perencanaan dan pembangunan yang berkelanjutan, serta meningkatkan kesejahteraan masyarakat. 
Penulis juga mendapat pelajaran tentang bagaimana perencanaan pembangunan dapat menentukan baik buruknya program dan kegiatan. Dengan perencanaan yang baik, maka tujuan pembangunan bisa dicapai. Melalui penelitian di lapangan, pemberdayaan adalah konsep yang tidak bisa langsung diproyeksikan keberhasilannya mengenai sebuah program. Hal tersebut karena prinsip keberlanjutan akan terus melekat pada empowerment. Namun, keberlanjutan yang dimaksud dapat menunjukkan bagaimana masyarakat menjadi kreatif dan inovatif untuk mempertahankan power yang ada dalam dirinya. Konsep pemberdayaan yang begitu mendalam, menciptakan kemungkinan-kemungkinan mengenai manfaat yang luas. Dikatakan luas karena bukan hanya masyarakat yang merasakan, pemerintah dan aspek-aspek lainnya ikut menerima manfaatnya. Dapat dikatakan bahwa dampaknya akan sangat baik bagi desa ataupun daerah. Mereka berdaya, ekonomi meningkat, dan daerah menjadi maju.

\section{DAFTAR PUSTAKA}

Afiyah, S. (2011). Strategi Pemberdayaan Masyarakat dalam Pembangunan Desa.

Anomsari, E. T., \& Abubakar, R. R. T. (2019). Program Pembangunan Partisipatif dan Dampaknya Terhadap Pemberdayaan Masyarakat. Jurnal Natapraja: Kajian Ilmu Administrasi Negara, 7(1), 121-138. https://doi.org/10.21831/jnp.v7i1.22157

Askar, A. (2019). Dimensi Keterlibatan Masyarakat Dalam Program Pembangunan. Jurnal Sosio Sains, 5(1), 53-61. https://doi.org/10.37541/sosiosains.v5i1.97

Erwinsyah, R., Atmojo, M. E., \& Pratiwi, V. P. (2020). Efektivitas Belabeliku.Com dalam Pemberdayaan Masyarakat Berbasis E-Commerce Kabupaten Kulon Progo Tahun 2018. Moderat: Jurnal Ilmiah Ilmu Pemerintahan, 6(3), 501-512. https://doi.org/10.25157/moderat.v6i3.3521

Firdaus, R. (2020). Peran Pemerintah Daerah Sebagai Regulator, Dinamisator, Fasilitator, dan Katalisator Dalam Pemberdayaan Petani Kakao Di Kabupaten Luwu Utara. Journal I La Galigo | Public Administration Journal, 3(1), 31-40.

Isyaroh, R. I., \& Atmojo, M. E. (2020). Efektivitas Toko Milik Rakyat (TOMIRA) dalam Mewujudkan Pemberdayaan Masyarakat di Kabupaten Kulon Progo Tahun 2018. FisiPublik: Jurnal Ilmu Sosial Dan Politik, 5(1), 49-65. https://doi.org/10.24903/fpb.v5i1.833

Mardlatillah, E. A. M., \& Hidayat, Z. (2019). Peran Pemerintah Daerah dalam Upaya Deradikalisasi Eks Napiter Di Wilayah Kota Semarang. Journal of Public Policy and Management Review, 8(4), 539-545-545. https://doi.org/10.14710/jppmr.v8i4.25128 
Murtiningrum, F., \& Oktoyoki, H. (2019). Perencanaan Pengembangan Kawasan Berbasis Pemberdayaan Review and Perspectives. JAS (Jurnal Agri Sains), 3(2), Article 2. https://doi.org/10.36355/jas.v3i2.290

Musa, M. (2017). Optimalisasi Peran Pemerintah dalam Pemberdayaan Masyarakat. Mawa'izh: Jurnal Dakwah dan Pengembangan Sosial Kemanusiaan, 8(1), 107125. https://doi.org/10.32923/maw.v8i1.700

Mustangin, Kusniawati, D., Islami, N. P., Setyaningrum, B., \& Prasetyawati, E. (2017). Pemberdayaan Masyarakat Berbasis Potensi Lokal Melalui Program Desa Wisata di Desa Bumiaji. Sosioglobal: Jurnal Pemikiran dan Penelitian Sosiologi, 2(1), 59-72. https://doi.org/10.24198/jsg.v2i1.15282

Mustanir, A. (2019). Pemberdayaan Masyarakat Kewirausahaan. OSF Preprints. https://doi.org/10.31219/osf.io/j9rx5

Mustanir, A., Hamid, H., \& Syarifuddin, R. N. (2019). Pemberdayaan Kelompok Masyarakat Desa Dalam Perencanaan Metode Partisipatif. MODERAT: Jurnal Ilmiah Ilmu Pemerintahan, 5(3), 227-239.

nakertrans.kulonprogokab.go.id. (2019). Disnakertrans-Tupoksi dan SDA. https://nakertrans.kulonprogokab.go.id/detil/2059/tupoksi-dan-sda

Rahayu, S., Dewi, U., \& Fitriana, K. N. (2016). Pengembangan Community Based Tourism sebagai Strategi Pemberdayaan Ekonomi Masyarakat di Kabupaten Kulon Progo, Daerah Istimewa Yogyakarta. Jurnal Penelitian Humaniora UNY, 21(1), 124561.

Soeprodjo, R. G., Ruru, J., \& Londa, V. (2020). Pemberdayaan Masyarakat Pesisir Pantai di Desa Inobonto Dua Kabupaten Bolaang Mongondow. Jurnal $\begin{array}{llll}\text { Administrasi } & \text { Publik, } & \text { 6(89), }\end{array}$ https://ejournal.unsrat.ac.id/index.php/JAP/article/view/28429

Ulum, M. C., \& Anggaini, N. L. V. (2020). Community Empowerment: Teori dan Praktik Pemberdayaan Komunitas. Universitas Brawijaya Press.

Widiyawati, A. T. (2020). Model Pengembangan Pemberdayaan Pengetahuan (Studi pada Perpustakaan Desa Paseban, Kec. Kencong, Kab. Jember). Tik Ilmeu: Jurnal Ilmu Perpustakaan Dan Informasi, 4(1), 77-96. 